\title{
TTR
}

Traduction, terminologie, re?daction

\section{Diplomacy Beyond Language: François Guizot and Translation}

\section{Gabriel Louis Moyal}

Volume 13, numéro 1, 1er semestre 2000

Idéologie et traduction

Ideology and Translation

URI : https://id.erudit.org/iderudit/037398ar

DOI : https://doi.org/10.7202/037398ar

Aller au sommaire du numéro

\section{Éditeur(s)}

Association canadienne de traductologie

ISSN

0835-8443 (imprimé)

1708-2188 (numérique)

Découvrir la revue

Citer cet article

Moyal, G. L. (2000). Diplomacy Beyond Language: François Guizot and

Translation. TTR, 13(1), 167-192. https://doi.org/10.7202/037398ar

\section{Résumé de l'article}

Au delà du langage, la diplomatie. François Guizot et la traduction — La critique s'intéresse généralement très peu à la traduction ou aux traducteurs des textes non littéraires écrits en France au début du XIXe siècle. Cependant, ce genre d'omission semble plus particulièrement volontaire dans le cas de François Guizot (1787-1874) qui, avant d'être nommé Premier ministre de la France ou ambassadeur en Angleterre, a traduit en français d'importants textes anglais. Les fondements de sa réflexion sur la différence linguistique apparaissent distinctement dans la représentation idéologique qu'il fait de l'histoire. Les écrits de Guizot sur l'histoire de la France et de l'Angleterre, ainsi que ceux traitant de l'évolution de la langue, semblent indiquer que la traduction deviendrait, avec le temps, une pratique désuète. Selon lui, les nations, tout comme les langues, se dirigeraient naturellement vers une unité ultime, une égalité utopique où les différences - politiques ou linguistiques seraient définitivement abolies.
Tous droits réservés (C) TTR: traduction, terminologie, rédaction — Les auteurs, 2000
Ce document est protégé par la loi sur le droit d'auteur. L'utilisation des services d'Érudit (y compris la reproduction) est assujettie à sa politique d'utilisation que vous pouvez consulter en ligne.

https://apropos.erudit.org/fr/usagers/politique-dutilisation/ 


\title{
Diplomacy Beyond Language: François Guizot and Translation
}

\author{
Gabriel Louis Moyal
}

\section{Lapsus linguæ}

In the first months of 1840 , shortly after his arrival in London as French ambassador and his first meetings with Lord Palmerston, the foreign minister, François Guizot, arranges to meet Lord Melbourne, the head of cabinet. Their conversation is an odd one - especially considering the diplomatic tensions between England and France at the time, the problems Guizot has been sent to resolve, and the very unstable nature of the French government he has been appointed to represent. Still, in his Mémoires many years later, when Guizot gives an account of this conversation, one aspect stands out: Guizot mentions the language - or rather the languages - in which the conversation took place. Until this point, and although he reports his conversations in apparently extensive detail, little has been said about the language used or whether interpreters are ever present. Until now, in this volume of his recollections devoted to his ambassadorship in England, all conversations have been reported in French as though French had been the seamless idiom of European diplomacy, or the translation of English diplomatic code into French was utterly unproblematic. Here however, perhaps carried away by the animation of his interlocutor still vivid in his memory, or by the image of the rather informal manner in which it was conducted, Guizot does mention that the conversation, without explicit previous agreement, took place in each one's own language. It is all as if, by the kind of tacit agreement possible only 
among well-bred gentlemen, mutual understanding could be assumed and each one's comfort of expression in his mother tongue indulged:

\begin{abstract}
Étendu dans son fauteuil à côté du mien, détournant la tête et penchant vers moi l'oreille, parlant anglais et moi français, chacun à notre tour et dans un dialogue régulier, interrompu seulement par ses rires, lord Melbourne m'écoutait et me répondait avec ce mélange d'insouciance et d'attention sérieuse qui indique une conviction libre plutôt qu'une intention préméditée, et qui semble appeler et autoriser un parfait abandon'.
\end{abstract}

Clearly, there is much more about this dialogue to recommend it to memory than simply the question of the languages used: the all-toorelaxed atmosphere (Melbourne is sprawled in his "fauteuil"), the apparently inadvertent admission by Guizot - charged at the time with a very delicate mission - that he was seduced into a sense of "abandon", and the consequent impression a modern reader might gather that, rather than a guarded diplomatic exchange, something like an analytic session is being described here with its unpremeditated, unprejudiced association of ideas.

What transpires about the languages here, though, is in terms of Guizot's other writings, intrinsic to political process - whether it be between nations or among the classes or the political interest groups of a same nation. Translation - previously invisible in Guizot's text - is here shown to be redundant. The absence of translation (and likely of interpreters) conspires to ease the situation. It affirms the sense of understanding, beyond or despite words and codes, that Guizot feels ultimately exists or ought to exist both within and between nations. Such understanding is, in Guizot's terms, provisionally deferred and entrusted to the privileged and educated classes of France and England until truly representative government can be brought about in those two countries and eventually in all of Europe.

Further on in this same volume of his Mémoires, Guizot recounts two occasions on which he was invited to make public speeches in his role as French ambassador. On both occasions, it turns

\footnotetext{
' François Guizot, Mémoires pour servir à l'histoire de mon temps, Paris, M. Lévy, 1872 [henceforth abbreviated as Mémoires ], vol. 5, p. 46.
} 
out, choosing the language of address demanded careful deliberation. At the same time, the account of his reasoning in both these cases reveals that, for all of his apparent formality, Guizot's ultimate decisions involved not just questions of protocol and propriety but also considerations of class. In both cases his hesitation reveals how intrinsically these matters are related to his own origins and to the personal ideology which evolved therefrom.

On recounting the first of these occasions, an invitation to speak at the Lord Mayor's Banquet ("le dîner de la Cité"), Guizot seizes the occasion to list the reasons for which he could count himself "populaire"2 with the English bourgeoisie. All his reasons are personal, pertaining to his Protestant faith - highly unusual for a French ambassador, his accomplishments as a scholar of English history and his own particular political affiliation:

J'étais populaire à Londres; depuis Sully et Ruvigny, j'étais le premier ambassadeur français protestant qu'on y eût vu; mes études historiques m'avaient valu l'estime des lettrés; politiquement on me connaissait à la fois comme libéral et comme conservateur; les whigs me savaient gré de mon attachement aux principes du gouvernement libre, et les torys de ma résistance aux tendances anarchiques ${ }^{3}$.

Warmly received by London's merchant class, "qui prenait plaisir à déployer ses magnificences et ses sentiments", Guizot chooses to speak in English: "Quand le lord maire eut porté ma santé [...] j'y répondis en anglais par un petit discours accueilli avec une satisfaction cordiale et bruyante".

${ }^{2}$ François Guizot, Mémoires, vol. 5, p. 124. Guizot's use of the term "populaire" in this particular context seems to compound the common English sense of "popular" into the French near-homonym. The latter today normally carries a pejorative connotation, bringing it closer to the English "plebeian".

${ }^{3}$ François Guizot, Mémoires, vol. 5, p. 124.

${ }^{4}$ François Guizot, Mémoires, vol. 5, p. 125. The extent of Guizot's enthusiasm can be gauged here, where, visibly still moved by the memory some thirty years later, he quotes a letter written the next day to Paris: '[...] tout cela m'a amusé et intéressé. Mais les hommes m'intéressent infiniment plus que les choses; et j'oublie tous les spectacles du monde pour des yeux qui s'animent en 
When, some days later, he is asked to address the Royal Academy as spokesman for the foreign diplomatic corps, Guizot falls back onto considerations of the dignity of his function. Unsure of which language would be more acceptable in this aristocratic audience, he seeks and obtains varying advice:

On était curieux de m'entendre, curieux aussi de savoir si je parlerais en français ou en anglais [...] lord Granville me fit dire, de Paris, qu'il lui semblait préférable que je parlasse anglais; mon impression fut différente; outre que le français $m$ 'était beaucoup plus commode, il me parut qu'un ambassadeur de France devait parler sa langue partout où il pouvait être compris, et $j$ 'avais la chance de l'être dans la réunion de l'Académie royale, du moins de la plupart des assistants; je ne l'aurais été de presque personne au dîner de la Cité. À la Cité d'ailleurs on n'avait vu dans mon médiocre anglais, que ma bonne volonté; à l'Académie royale, on verrait surtout mon mauvais accent ${ }^{5}$.

That his decision was judicious becomes clear a little further on when Guizot, having summarized his speech to the Royal Academy (the arts flourish when there is peace between great nations, etc.), modestly draws the conclusion that he was perfectly understood: " $A$ l'accueil que reçurent ces paroles, je ne pus pas douter qu'elles n'eussent été comprises et approuvées"'.

In the end, Guizot's decision to speak French is not determined by protocol or even by received diplomatic wisdom (Lord Granville's advice) but rather by what he can himself justify as appropriate. The choice of language turns out, in the end, to be an issue, but one which, even in this context of high-level diplomacy, appears not to be ruled by explicit guidelines. Decisions seem to be left

m'écoutant et des figures graves et timides qui me parlent avec une émotion bienveillante."

${ }^{5}$ François Guizot, Mémoires, vol. 5, pp. 126-127. Lord Granville was the British ambassador in Paris. That Guizot should have sought his advice on the language expected by protocol in this situation is of some interest in view of his final decision.

${ }^{6}$ François Guizot, Mémoires, vol. 5, p. 129. 
at the discretion of the individual diplomat in his posting. Consequently, Guizot's choice of language becomes, in the text of his Mémoires, exemplary of his tact, of his ability to instinctively gauge his interlocutors. In the text, such instances become as many samples of his diplomatic skill, tokens of his natural competence. An effect which is accentuated when viewed some thirty years later, when the consequences of all such discretionary decisions have had the time to play themselves out historically. Guizot's talents can then, as Guizot well knows, be judged for their true worth.

Yet, here, in the justifications he provides for his choices, Guizot allows hints of his own political leanings to transpire. Between the policies of the government he is duty-bound to represent and the limited freedom he is accorded as to the means of representing it, Guizot contrives to demonstrate not only the propriety of the particular discretionary decisions he has taken, but the righteousness of the ideology - his own - on which they were drawn. Deciding which language to use in the two situations Guizot has described immediately involves determining the level of education which can be expected: educated aristocrats will surely know French; the bourgeoisie at the Lord Mayor's banquet, although prosperous and ostentatious, has not yet grasped the potential mercantile advantages of learning foreign tongues. With the former, as with Lord Melbourne, mastering French is consonant with their unquestioned power; imposing on them a speech in French becomes a way of implicitly asserting equality of status. For the "diner de la Cite", the pleasant condescension of a heavily accented English is a sufficient mark of good will?

\footnotetext{
${ }^{7}$ Whereas Guizot's summary of his speech to the Royal Academy stretches over some three pages, his address to the crowd at the Lord Mayor's banquet is, as noted, simply described as "un petit discours accueilli avec une satisfaction cordiale et bruyante." (François Guizot, Mémoires, vol. 5, p. 125) In Larousse's famous Grand Dictionnaire universel du XIXe siècle français, published around the same time as Guizot's Mémoires, the generally hostile entry on Guizot makes a point of commenting on the ambiguities of class and ideology the diplomatic post must have occasioned: "Nommé ambassadeur à Londres (février 1840), M. Guizot, à demi Anglais par l'éducation, les sentiments, la religion. les mours, enfin par quelques-uns de ses grands travaux littéraires, ne pouvait manquer d'être bien accueilli par l'aristocratie
} 
This apparently discriminatory attitude only partially reflects Guizot's consistent political positions. He strongly believes in democracy, and even more strongly in liberty. Yet for him, true democracy must be the result of a protracted - though historically inevitable - constitutional process. From his historical perspective, sudden and violent revolutions - as the lapsing of the French Revolution into the Terror amply demonstrates - have only set back the continuous progress towards true and natural democracy. Good government can only be the result of the cooperation of all classes, of all interest groups. Guizot's apparent condescension towards the English (or French) bourgeoisie is not founded on snobbery, on demeaning class prejudice. He is too self-aware and, in the end, too proud of his own bourgeois origins to maintain so contradictory a view. His perception of the English merchant class is predicated on the stage of political evolution it has attained. In England, more so than in France, the bourgeoisie has, according to him, advanced towards true democracy only by allying itself with the aristocracy in the struggle to gradually wrest freedoms from absolute monarchy. In what Guizot sees as an ineluctable process of "trickle-down" democracy, the English bourgeois are progressing towards egalitarian and, ultimately, truly democratic government. And what for him constitutes ideal government cannot fail but appear utopian when compared with historical reality, with the context of infinitely splintered confrontational politics which served as background to its conception.

Still, for Guizot attaining good, responsible government is a matter determined mostly by patience and adequate consideration of the interests of others. In good time, as the democratic trends Guizot identifies inevitably gather strength, all classes will reach the level of education, wisdom and good sense that will render them capable of responsibly ruling themselves in a perfectly egalitarian state. Equality in his sense is inevitable because, in the end, it is the only political basis on which energies in conflict can come to resolution. Without constitutionally recognized equality, anarchy and endless conflict inevitably become the norm and civilized society becomes impossible.

britannique, malgré la simplicité bourgeoise de ses manières. Mais son rôle diplomatique fut loin d'être brillant." 
The promise of equality is the only mode of bringing conflicting energies to wear themselves out and seek resolution in legal coexistence:

Tout pouvoir humain dis-je, porte en lui-même un vice naturel, un principe de faiblesse et d'abus qui doit lui faire assigner une limite. Or il n'y a que la liberté générale de tous les droits, de tous les intérêts, de toutes les opinions, la libre manifestation de toutes les forces, leur coexistence légale, il n'y a, dis-je, que ce système qui puisse restreindre chaque force, chaque puissance dans ses limites légitimes, l'empêcher d'empiéter sur les autres, faire, en un mot, que le libre examen subsiste réellement au profit de tous'.

In the meantime, the lower classes must learn to cooperate with the higher and, in the process, glean from them all the enlightenment and advantages they can. The lower classes are, only for now, in a humbler position because of their lesser abilities, of unrealized potential. In the meantime, political evolution appears as a process somewhat analogous to that of natural selection, according to Guizot: "En tout, dans le monde livré à son cours naturel, l'inégalité naturelle des hommes se déploie librement et chacun prend la place qu'il est capable d'occuper". Individuals, in Guizot's sense of historical process,

${ }^{8}$ François Guizot, Histoire générale de la civilisation en Europe depuis la chute de l'Empire romain jusqu'à la Révolution française, Bruxelles, Gregoir, Wouters \& Cie., 1840 (1829-32); [henceforth abbreviated as Histoire], p. 269. This theme is also the principal conclusion of the English translator's introduction to one translation of this text - an introduction visibly quite heavily influenced by Guizot himself: "Constitutional government is the cooperation of the various powers in a state, and not their separation. It requires not aristocracy to be opposed to democracy, nor democracy to make war upon aristocracy. [...] It requires nothing, in short, but that one single will should be brought out from the fusion of various wills; but then to obtain this single will every class or society must be heard, all their interests must be consulted, all their causes must be pleaded, and upon every question, the highest virtue to be found in the country, enlightened by the highest intelligence, must pronounce judgement without appeal." "Translator's Introduction" in François Guizot, General History of Civilization in Europe from the fall of the Roman Empire to the French Revolution, Oxford, D. A. Talboys, 1837 [henceforth abbreviated as History], p. viii.

${ }^{9}$ François Guizot, Histoire, p. 95. 
naturally gravitate to the social class, to the level of power, their abilities can obtain.

Whatever ensuing class struggles this process may have occasioned along the way, in the end, according to Guizot, things have always drifted towards conflict resolution, towards stability and order. Thus, in his version of class struggle, "la lutte des classes", the end result has always shown itself to be the advancement of civilization:

Les classes ont lutté constamment; elles se sont détestées; une profonde diversité de situation, d'intérêts, de mours, a produit entre elles une profonde hostilité morale : et cependant elles se sont progressivement rapprochées, assimilées, entendues; chaque pays de l'Europe a vu naitre et se développer dans son sein un certain esprit général, une certaine communauté d'intérêts, d'idées, de sentiments qui ont triomphé de la diversité et de la guerre ${ }^{10}$.

What draws Guizot to England - as a historian as well as a political scientist - is the exemplary way in which English history has followed that, for him, necessary path of political evolution. In the first few pages of his Mémoires, Guizot summarizes what in effect has been the subject of much of his previous writings on the history of England. Almost inevitably the summary turns into a lesson illustrated by comparisons with French history. Not surprisingly, the bases of his comparisons are the various revolutions through which the two nations have struggled. What, in the end, shines through Guizot's summary is the near-pervasive idealization of English historical evolution, the near perfect meshing of each stage of development with what appears, with historical hindsight, as a logical, orderly progression towards democracy. If Guizot's ideals of government and democracy had more explicitly been fashioned on England's constitutional history they would not appear much different.

Thus, in an implicit comparison of the English version of democracy with the French, Guizot underlines what for him was the fundamental difference: the union of all classes - led by the aristocracy - against absolutism and for liberty and equality. Even if,

${ }^{10}$ François Guizot, Histoire, pp. 143-144. 
for a moment, the lower classes prematurely seized power in England, any change they may have effected was superficial and temporary: "ce n'a été là qu'une crise superficielle et passagère." What preserved the English system was the continuing commitment of all classes to freedom: "l'esprit de liberté était le vrai mobile du pays." And so, indulging in his own revision of the English revolutions, Guizot shows them to have been motivated by a spirit of freedom shared by the aristocrats and the middle class - which he here, in contrast, calls "la démocratie":

[...] une grande portion de l'aristocratie soutenait la cause des libertés publiques, et le peuple se groupait de bon cour autour d'elle comme autour d'un chef allié nécessaire et d'un chef naturel. La Révolution d'Angleterre $a$ été de 1640 à 1660, bien plus aristocratique, et en 1688, bien plus démocratique qu'on ne le croit communément; la démocratie a paru dominante en 1640 et l'aristocratie en 1688; mais à l'une et à l'autre époque, ce sont l'aristocratie et la démocratie anglaises, animées du même esprit et intimement unies, qui ont fait ensemble, pour la défense ou le progrès de leurs libertés communes, l'un et l'autre de ces grands événements ${ }^{11}$.

As Guizot perceives it, this union of classes in the name of freedom offers the ideal model, the archetype of political developments. Its effect is not limited, in his eyes, to the two revolutions; rather, such an alliance ensures peaceful progression, a natural equilibrium where each class and each citizen within that class will attain the level of political power warranted by her/his natural abilities. Nowhere in his account of the history of English revolutions (as opposed to his perception of the French Revolution and the Terror) is power ever usurped by individuals unfit for government. What Guizot sees, in this visibly idealized account, are the guarantees of stable continuity, most particularly in the aristocracy's undertaking to induct those children of "la démocratie" who show talent into the higher realms of political power:

${ }^{11}$ François Guizot, Mémoires, vol. 5, p. 7. 
[...] l'aristocratie n'a été ni souveraine ni anéantie; la démocratie n'a été ni impuissante ni souveraine. La société anglaise n'a pas été bouleversée de fond en comble; le pouvoir n'est pas descendu des régions où il doit naturellement résider, et il n'y est pas resté isolé et sans communication avec le sol où sont ses racines. Les classes élevées ont continué de diriger le sort du pays, mais à deux conditions : l'une de gouverner dans l'intérêt général et sous l'influence prépondérante du pays lui-même; l'autre de tenir leurs rangs constamment ouverts et de se recruter, de se rajeunir incessamment en acceptant les nouveaux d'élite qu'enfante et élève le mouvement ascendant de la démocratie. Ce n'est pas le gouvernement aristocratique de l'antiquité ou du moyen-âge; c'est le gouvernement libre et combiné des diverses forces sociales et des influences naturelles qui coexistent au sein d'une grande nation ${ }^{12}$.

Perhaps, given this evident infatuation with things English, given his appreciation of the English mode of resolving political conflict and advancing democracy, Guizot's apparent indifference, earlier, to the language used in diplomatic encounters, his sentiment of natural ease in his bilingual exchange with Lord Melbourne obtain larger meaning. Feeling himself, in his posting, that much closer to the ideal state of government he could until then only write of, Guizot begins to blur away the very real differences between the nation with which he is commissioned to negotiate and the one he represents. Perhaps then, the scene of inadvertent, undue confidence with the British prime minister he has allowed himself to reveal stems from anticipatory enthusiasm, from a sense of already being within the nation he has always dreamt of building.

Some eight years after his posting in London, Guizot's failure as prime minister of France will have, in part, brought on the fall of the July Monarchy and the revolution of 1848 . Guizot will be forced to hide and leave France. Disguised as a workman, he will seek and obtain refuge in England.

\section{Lapsing Language and History}

${ }^{12}$ François Guizot, Op. cit., vol. 5, pp. 7-8. 
To some extent, in not previously making explicit which language was used in his negotiations or whether any use had been made of interpreters, Guizot is simply following widespread practice in nineteenth-century French political writing. Large circulation newspapers which, on a daily basis, carried numerous items gleaned from the foreign press hardly, if ever, made mention of the fact that these were translations - and even less of who the translators were. What was seen as essential or pertinent in political reports, documents and declarations was what could be identified, on a given question, as their direct, diplomatic or material effect. Meaning was implicitly assumed to be unambiguous and directly available through almost any mode of translation. Problems of expression, context, style or register, even where the translations were as vital as international treaties, diplomatic correspondence and negotiations, were not normally considered relevant. Questions as to the quality of a given translation were deemed pertinent only with regard to literary texts. In most other contexts making explicit that a given text was in fact a translation was unusual or would normally be accompanied by some form of justification such as the rectification of a previous gross mistranslation. Such is the case, for example, with this "Translator's Note" to the second translation of a relatively successful political book review by Guizot:

The following Essay by M. Guizot appeared in a recent number of the "Revue Française" and can only be obtained in the original by the Subscribers to that Review. It has created a powerful sensation, not only in Paris, but throughout the Continent, and shortly after its appearance in that Capital it was translated into German, and received with much approbation. The Translator is aware that this Essay has already appeared in English; but without for a moment supposing that his own Translation is free from errors, he feels justified in remarking, that the one to which he alludes is executed in a careless manner, and in many instances distorts the meaning of the Author ${ }^{13}$.

${ }^{13}$ François Guizot, Democracy in Modern Communities, "translated from the French of M. Guizot”, London, C. \& H. Senior, 1838. 
Despite the relatively exceptional inclusion of this "Note", the absence of any indication as to who either the previous or the present translators might be anywhere in the publication conforms to the then current publication norms for non-literary translation ${ }^{14}$.

But this exclusion of the translators' names - even in a translation of one of his own texts - is in no way attributable to Guizot alone. Guizot had himself translated or, with his first wife and other scholars, participated in the translation of several important English texts into French ${ }^{15}$. He had, for example, collaborated on, and written long prefaces to a re-translation of the works of Shakespeare. And, apart from numerous lengthy asides, in his historical writings, on the evolution of languages, Guizot authored a dictionary of French synonyms which remained a standard reference text for over seventy years. If he does seem to go along with the dominant attitude of taking translation of meaning for granted, of leaving translators and the work of translation as "invisible", it is likely because, in his prophetic vision of history, translation - particularly between French and English will ultimately become obsolete. This can likely best be understood by bringing into parallel some of his writings on language and on history.

\footnotetext{
${ }^{14}$ An asterisk after the word "German" at the end of the first paragraph quoted above directs the reader to a footnote in which the German title, the publisher and the name of the German translator are supplied. Perhaps an even more ironic instance of anonymity in translation, in connection with Guizot, can be found in the English version of Guizot's Shakespeare and his Times, which, despite a lengthy preface by Guizot himself on the particularities of translating Shakespeare, does not bear the names of the translator. See François Guizot, Shakespeare and his Times, London, Richard Bentley, 1852.

${ }^{15}$ Among the works in English which Guizot translated, or took part in the translation of are: Gibbon's Decline and Fall of the Roman Empire, (an abbreviated version of this translation is still the one most readily available in French today), the complete Works of Shakespeare (re-translated in large part by his first wife, Pauline de Melan, and prefaced by Guizot's Shakespeare and His Times (see above note 14), George Washington's Lettres, discours et écrits, and Stanhope's William Pitt and his Times. For a complete list of his translations and an extensive bibliography with manuscript sources, see Gabriel de Broglie's Guizot, Paris, Perrin, 1990.
} 
Much of what Guizot has to say about language has gone unnoticed or simply been subordinated to his historical or political views. Undoubtedly, much in his linguistic writings - the ever-present reliance on history - justifies such subordination and consequent neglect. Guizot's introduction to his own Dictionnaire universel des synonymes (1809), for example, is saturated with illustrations and references gleaned from historical and political philosophy. The first example he gives and analyses is "Peuple, Nation." As well, he argues that the "proper" non-metaphorical meaning of words (sens propre) is, not surprisingly, best determinable by its etymological sense, via its earliest traceable meaning:

L'étymologie apprend aussi à connaître le sens primitif et par conséquent le sens propre des termes [...] elle est le seul flambeau à la lumière duquel on puisse étudier les langues, et surtout les rapports de synonymie qui existent entre les mots ${ }^{16}$.

Yet, as becomes evident somewhat further on in the introduction, Guizot's perspective on language is not as rigidly limited as such statements might suggest. Etymology, it turns out, serves only as marker, as an arbitrary starting point, but one more reliable than most others previously used in other dictionaries of synonyms. After very briefly discussing etymology and illustrating its claims with examples of onomatopoeia, Guizot goes on to demonstrate the frailty of all single-minded explanations of the evolution of language. What motivates this attenuation of the importance of etymology is a more elaborate horizontal (rather than strictly chronological) perspective: his taking into consideration the reciprocal influences of languages which come into contact:

Comme il arrive souvent que de deux mots synonymes, le premier est emprunté à une langue, le second à une autre, il importe de connaitre leur sens dans la langue originaire, afin de savoir quelle est leur acception propre dans la nôtre: je prendrai pour exemple les

\footnotetext{
${ }^{16}$ François Guizot, Dictionnaire des synonymes de la langue française, Paris, Librairie Académique, Didier et cie., 1873 (1809) [henceforth abbreviated as Dictionnaire], p. XIV. This introduction and the rest of his dictionary, as Guizot indicates in a note, have in no way been changed since the first edition in 1809.
} 
synonymes bannir, exiler [...] Cet exemple suffit pour montrer que l'on peut souvent, avec fruit, appeler à son secours la connaissance des langues étrangères; mais c'est un moyen dont il ne faut user qu'avec circonspection. En passant d'une langue à l'autre, les mots changent, pour ainsi dire de patrie; leur ancienne figure, leur première signification s'altèrent et se décomposent : ce serait donc à tort qu'on voudrait tirer de leur origine des inductions positives; c'est un guide qu'on peut consulter mais qu'on ne doit pas toujours suivre ${ }^{17}$.

Here again, his choice of examples, "bannir, exiler" and of explanatory image, "patrie", are not purely coincidental. Their political connotations serve to illustrate the very mechanisms Guizot exposes as the mode of transfer of terms from one language to another: such words are either "banished" or "exiled". They have crossed national borders by choice ${ }^{18}$ or by force, and the meanings they acquire in the language of adoption end up rendering them foreign to their language of origin. All the more so as his definition of synonyms excludes perfect synonymy on the grounds that such synonymy would imply the presence of two languages within one and the same. The inescapable conclusion is that borrowed terms have been made to fit into the language, they have been made to cover only those meanings, shades of meaning or connotations which the existing terms of the host language do not cover. Treating etymologically rooted terms (mostly Latin) and words borrowed from contemporary languages on terms of equality implies at once the natural adaptability of languages to receive or to enter other languages and, ultimately, the foreigness to itself of the "host" language as a whole. Borrowed terms - like foreign diplomats who forget their allegiance in their posting - can, fortunately, be naturalized: they are integrated into their new language all the more easily as that language itself (like all others) naturally consists of derivations and borrowings ${ }^{19}$.

${ }^{17}$ François Guizot, Dictionnaire, pp. XIV-XV.

${ }^{18}$ Guizot refers to the Latin sense of exsilium as self-exile which survives in French of that time. 
But words are not alone in their travels. The historical perspective Guizot imports into the study of synonyms and more generally of meaning allows him to incorporate other, more current factors. Habits and morals, changing opinions and technical innovations all have a profound effect on terms, on the evolution of their meaning. In the end, for Guizot, language is at the mercy of history and hence vulnerable to endless mutations:

Ajouterai-je enfin que pour déterminer le sens propre des termes, il faut connaitre l'histoire des moeurs, des usages de la nation qui les emploie, et de celle à qui ils ont été empruntés [...] La langue est intimement liée avec les habitudes, les principes de ceux qui la parlent; elle en dépend comme l'image dépend de l'objet, comme le signe dépend du signifié [...] Que l'on suive l'histoire de la langue française depuis François ler jusqu'à nos jours, en la comparant avec celle de nos mours et de nos coutumes, on sera frappé de leur conformite ${ }^{20}$.

To illustrate this point in the Dictionnaire, Guizot cites examples which, in this connection, have now become common: "honnête homme", "libertin", etc. When, at the beginning of his course on the history of European civilization, he needs to define the term "civilization", he takes up a similar point about language and social values, about the influence of political institutions on the meanings of words. Yet, unexpectedly for the author of a respected dictionary, he dismisses the recourse to the scientific definitions of terms preferring instead the natural drift of popular usage, the meanings cobbled together by common folk and good sense:

\footnotetext{
${ }^{19}$ Linguistic nationalism - like other forms of nationalism - is not a strong suit in Guizot's writings. The very beginning of his introduction to his Dictionnaire des synonymes relegates the traditional thetoric of national linguistic pride to a secondary position in favour of more pragmatic advantages: "Ce n'est pas d'après le nombre des mots qu'il faut calculer la richesse d'une langue, mais d'après celui de leurs valeurs et des idées qu'ils expriment." François Guizot, Dictionnaire, p. XIII.

${ }^{20}$ François Guizot, Dictionnaire, pp. XV-XVI. Guizot's use of "signe" and "signifie" here, although original, are clearly different from Saussure's.
} 
C'est le bon sens qui donne aux mots leur signification commune, et le bon sens est le génie de l'humanité. La signification commune d'un mot se forme successivement et en présence des faits; à mesure qu'un fait se présente, qui paraît rentrer dans le sens d'un terme connu, on l'y reçoit, pour ainsi dire, naturellement; le sens du terme s'étend, s'élargit, et peu à peu les divers faits, les diverses idées que en vertu de la nature des choses mêmes, les hommes doivent rallier sous ce mot, s'y rallient en effet ${ }^{21}$.

Common usage is sensitive to fluctuations and reflects a community's adaptation to changing realities. On the other hand, scientific work is carried out in isolation and tends to reflect personal prejudice, to respond to momentary influences in possibly very narrowly defined situations. Its effect on language tends to be artificial:

Lorsque le sens d'un mot, au contraire, est déterminé par la science, cette détermination, ouvrage d'un seul ou d'un petit nombre d'individus, a lieu sous l'empire de quelque fait particulier qui a frappé leur esprit. Ainsi, les définitions scientifiques sont, en général, beaucoup plus étroites, et, par cela seul, beaucoup moins vraies au fond que le sens populaire des termes ${ }^{22}$.

This preference for the common usage meaning of terms does not imply vagueness or uncertainty for definitions - quite the contrary. For Guizot, common usage makes a tight fit both with the constellations of other terms in an idiom and with the realities it represents: "Quand une société a duré longtemps, et sa langue aussi, les mots prennent un sens complet, déterminé, précis, un sens légal, officiel en quelque sorte"23. And grammar, which, once codified, acts to

${ }^{21}$ François Guizot, Histoire, p. 19.

${ }^{22}$ François Guizot, Histoire, p. 19.

${ }^{23}$ François Guizot, Histoire, pp. 135-136. He adds: "Le temps a fait entrer dans le sens de chaque terme une multitude d'idées qui se réveillent dès qu'on le prononce, et qui, ne portant pas toutes la même date, ne conviennent pas toutes au même temps. Les mots servitude et liberté, par exemple, appellent aujourd'hui dans notre esprit des idées infiniment plus précises, plus complètes que les faits correspondants des VIII,$L X^{e}$, ou Xe siècles." 
regulate linguistic exchange - as a constitution regulates exchanges between a state's government and its people - grammar also shelters the language from excessive variation and maintains some unity ${ }^{24}$.

But language comes to resemble history in yet another, more important, sense in Guizot's perspective. Like history for those who live it and make it, language escapes the grasp of those who use it. Like history, language results from a multitude of variables too numerous to account for. History, for Guizot, cannot be the simple chronological organization of known or probable facts. If it is to serve any purpose at all, history must provide some understanding of causes and resulting situations. And just as, for him, individual, and even scientific input into a language has to be suspected of partiality and distortion, Guizot emphasizes the danger of concocting an interpretation of history founded on its individual actors. Even isolating individuals from the collective interwoven motions which make up history is an impossible task. In the inaugural lecture of his 1812 course in Modern History, Guizot accentuates the intractability, the inextricability of simple facts, of individual actors - no matter how exceptional - in the study of history. At the same time, he implicitly opposes these difficulties to the very powerful motivations for understanding history which, by the successive and very massive upheavals he has witnessed, confront his times:

Composé obscur d'une infinité de sentiments et d'idées qui $s$ 'altèrent, se modifient réciproquement et dont il est aussi difficile de démêler la source que d'en prévoir les résultats, produit incertain d'une multitude de circonstances, quelquefois impénétrables, toujours compliquées, qu'ignore souvent celui qu'elles entraînent, et que ne soupçonnent même pas ceux qui l'entourent, l'homme sait à peine se connaître lui-même et n'est jamais que deviné par les autres [...] Et que d'hommes dans un événement! Que d'hommes dont le caractère a influé sur cet événement, en a modifié la nature, la

24 Cf. Dictionnaire, pp. XV-XVI: "cette liaison [between 'signe' and 'signifié'], moins sensible lorsque la grammaire formée et perfectionnée s'est mise à l'abri de la variation des opinions." 
marche, les effets! [...] C'est de cette infinité de détails, où tout est obscur, où rien n'est isolé, que se compose l'histoire ${ }^{25}$.

Humans are the unconscious actors in their own history because they cannot foresee all the ramifications of their actions. They are convinced they are accomplishing one thing, and the political and historical perspective of historians and thinkers like Guizot reveals them as doing another altogether. As the interview with Lord Melbourne already exemplifies, Guizot himself, on writing his Mémoires, will have to confront this truth he could not yet have been aware of so many years before becoming himself a key figure in European history.

If individual actors are ultimately unaware of the sense of their actions in the larger context of history, all the more so are nations. Only long-term historical perspective can trace the path chosen, can make sense of the directions taken and relate them to a purpose unconsciously adopted yet ineluctably attained. This is what Guizot will endeavour to show in his survey of European history: only by looking very far back from a given political conjuncture is it possible to retroactively endow past historical actions and decisions with rational intent and meaning. Tracking patterns, showing developing trends is, according to him, possible only from a chronologically distant vantage point. Peoples, nations - all of Europe - remain unconscious actors in the meantime. And the dominant trends which Guizot traces out for Europe are those towards greater unity, greater unification.

In his course on European history, centralization proves to be the direction Europe has been unconsciously following ever since the fourteenth century:

Elle [l'Europe] ne savait point distinctement ce qui lui manquait, ce $q u$ 'elle cherchait. Cependant elle s'est mise à le chercher comme si elle l'avait bien connu [...] l'Europe entra naturellement et comme par instinct dans les voies de la centralisation. C'est le caractère du $X V$ siècle d'avoir tendu constamment à ce résultat, d'avoir travaillé à créer des intérêts généraux, des idées générales, à faire disparaitre

${ }^{25}$ François Guizot, Discours prononcé pour l'ouverture du Cours d'histoire moderne de M. Guizot, le 11 décembre 1812, cited in Mémoires, vol. 1, p. 389. 
l'esprit de spécialité, de localité, à réunir, à élever ensemble les résistances et les esprits [...] travail accompli sans préméditation, sans dessein, par le cours naturel des événements ${ }^{26}$.

This centralizing trend of Europe is, for Guizot, part of the general motion of history. The plan may be unknown to the players but the enlightened perspective of history makes it evident. It is, in some of Guizot's moments of prophetic rhetoric, the divine plan for the world: a return to perfect equality as all humans ultimately appear before God.

Guizot's insistence that the control of history and of language is not in the hands of individuals but is subject only to the irresistible unifying currents of history goes some way to explain Guizot's apparent indifference to making translation explicit - despite his own efforts as a translator. The unification of England and France is to his mind a far more precious end than any conceivable recognition or reward for translating even the most significant texts. A measure of his conviction and of the value he attaches to that goal appears in the very clear sense of anticipation which emanates from much of his writings. More significant and paradoxical are his own attempts to take deliberate control, to make the decisions and take the steps which, in his estimation, would bring about the desired union.

\section{Translating with abandon}

Perceiving and understanding the flow of history seems to him to impose the responsibility of political action. Even early on, in his 1821 history course, Guizot tells his students that it is no longer acceptable to simply know and deplore with great condescension the rest of society's ignorance: one must spread the word and bring others to consciousness and to deliberate political action. This becomes especially important in the face of political opposition generated by short-sighted interests. Theory alone, even perfect knowledge, comes to appear insufficient: in one of the Hegelian moments of his course Guizot proclaims the necessity of uniting theory and reality, knowledge and practice:

${ }^{26}$ François Guizot, Histoire, p. 201. 
[...] l'état actuel du monde nous impose la loi d'accepter franchement cette inévitable alliance de la philosophie et de l'histoire. Elle est précisément l'un des caractères, peut-être le caractère essentiel de notre époque. Nous sommes appelés à considérer, à faire marcher ensemble la science et la réalité, la théorie et la pratique, le droit et le fait 27.

The risk, for him, of not assuming political responsibility is that control over the unschooled, undisciplined masses will be left - as the example of the French Revolution and the Terror have shown - to ignorance and unprincipled fanaticism. Those who are capable of understanding actual situations and of fitting them into the larger scheme, into the flow of history, have the duty of preventing such outcomes:

Pour gouverner, pour prévaloir parmi les hommes, il faut maintenant connaître, comprendre et les idées générales et les circonstances; il faut savoir tenir compte des principes et des faits, respecter la vérité et la nécessité, se préserver de l'aveugle orgueil des fanatiques $[. . .]^{28}$

When Guizot returns to France, late in 1840, he has the chance to give body to his own teachings. Although he officially only assumes the portfolio of foreign minister, he is, in effect, head of the cabinet and thus of the government. ${ }^{29}$ The responsibility to fulfill the nation's historical destiny as he has understood and outlined it now rests on his shoulders. Nonetheless, his attempts to, as it were, anticipate history, to rush the drift he thought irresistible, failed miserably. How much he had tried to facilitate the kind of unification that he had earlier identified as the inevitable motion of history - at least in regard to France and England - can be gauged in the following admission in another passage of his Mémoires:

27 François Guizot, Histoire, p. 72. On Guizot's acquaintance with Hegel's writings, see Claude Lefort's "Guizot : le libéralisme politique" in Écrire à l'épreuve du politique, Paris, Calmann-Lévy, 1992, pp. 113-139.

${ }^{28}$ François Guizot, Histoire, pp. 72-73.

${ }^{29} \mathrm{He}$ will only officially assume the Présidence $d u$ Conseil in 1847 , one year or so before the revolution of February 1848. 
Je n'hésite cependant pas à le reconnaître : dans notre travail d'organisation politique, nous avons quelquefois fait d̀ l'Angleterre des emprunts trop complets et trop précipités. Nous n'avons pas toujours tenu assez de compte du caractère propre et des conditions spéciales de la société française. La France a grandi et a prospéré sous l'influence de la royauté, secondant l'ascension des classes moyennes; l'Angleterre, par l'action de l'aristocratie territoriale, prenant sous sa garde les libertés du peuple. De telles différences sont trop profondes pour disparaître, même dans la puissante uniformité de la civilisation moderne ${ }^{30}$.

The error admitted to, many years after the facts, is not solely the premature haste with which some adaptations of English constitutional process might have been attempted. It is also the recognition of a misreading, of a misunderstanding of the circumstances and of the nature of the two nations. Yet, for all that, in the same pages, Guizot returns to the theme of an unconscious affinity and to that of the inevitable union of the two nations:

Quand on compare attentivement l'histoire et le développement social de la France et de l'Angleterre, on ne sait si c'est des ressemblances ou des différences qu'on doit être le plus frappé. Jamais deux nations avec des origines et des situations fort diverses, n'ont été plus profondément mêlées dans leurs destinées, et n'ont exercé l'une sur l'autre [...] une plus constante influence ${ }^{31}$.

But in developing his point, Guizot makes a revealing attenuation of his bias, one which perhaps helps to account for the ultimate failure of his efforts to bring France and England closer — both diplomatically and in constitutional structure:

Les deux nations, ou pour parler plus exactement, les hautes classes des deux nations ont eu tour à tour la fantaisie de s'emprunter mutuellement leurs idées, leurs mours, leurs modes [...]. C'est donc une vue bien superficielle et bien erronée que celle des personnes qui regardent la société française et la société anglaise comme si essentiellement différentes qu'elles ne sauraient puiser l'une chez

\footnotetext{
${ }^{30}$ François Guizot, Mémoires, vol. 1, p. 320.

${ }^{31}$ François Guizot, Mémoires, vol. 1, p. 318.
} 
l'autre des exemples politiques, si ce n'est par une imitation factice et stérile $e^{32}$.

The doubters, those who have caused the failure of his efforts, Guizot implies, were not entitled to act politically because, in the end, they were, by their lack of proper perspective, by a short-sightedness consonant with their class origins, unable to see the direction history was taking. If Guizot admits error, if he accepts fault for his attempts to rush history and for misreading the circumstances at a given time, he does not admit error in his reading of the overall trends of history. In what seems to be for him an irresistible projection, an obsessive conviction, he demonstrates by constant reiteration what for him is the destined fusion of the two peoples:

[...] soit qu'ils le sachent ou qu'ils l'ignorent, qu'ils le veuillent ou qu'ils s'en défendent, ils ne peuvent pas ne pas influer puissamment l'un sur l'autre; leurs idées, leurs moeurs, leurs institutions se pénètrent et se modifient mutuellement, comme par une invincible nécessitét ${ }^{33}$.

If Guizot's certainty, by this constant repetition, appears somewhat less than serene, its persistence in the face of numerous reversals remains nonetheless admirable. In one other instance, translation makes Guizot's prophecies appear - at least momentarily — fulfilled. In the 1840 edition of his Histoire générale de la civilisation en Europe, the editors decide to publish the text of the course complete with a translation into French of the "Translator's Preface" to the 1837 English translation of that text ${ }^{34}$. A "Note de l'éditeur" indicates that there have been three translations of Guizot's course into English and

${ }^{32}$ François Guizot, Mémoires, vol. 1, p. 319.

${ }^{33}$ François Guizot, Mémoires, vol. 1, p. 320.

${ }^{34}$ François Guizot, History, The "Translator's Preface" runs from p. iii to p. ix. No translator is specifically named but a short note at the end of the preface indicates that two or more translators shared the work: "It should perhaps be stated, that one or two of the latter lectures are not translated by the same hand as the rest, though to ensure uniformity, he has carefully revised them." (p. ix) 
that "celle de M. Talboys, publiée à Oxford en 1837, est précédée d'une préface qui, par l'élévation et la justesse des idées, nous a paru mériter d'être mise sous les yeux des lecteurs français"3s.

What, to modern readers, is remarkable about the translation and inclusion of this preface is that no effort had been made to adapt or explain the English translator's cultural and political assumptions. It is clear throughout that the preface's English author has read Guizot's political writings extensively. Many passages of the preface appear to be re-phrasings of passages in other texts by Guizot. Guizot's political principles are wholeheartedly praised. Yet this approval is founded on Guizot's own approval and implicit assimilation of British constitutional process and democratic traditions. Indeed, the assimilation appears so thorough that the English translator speaks of the General History of Civilization as though it were explicitly and principally focused on England and English history rather than - as it is in fact - on French history:

The following lectures of Professor Guizot, calculated as they are, in their whole scope and tenour, to exalt, establish, and render more beautiful, the whole frame-work of the great social system to which we belong, and which has secured to us so many of the rights and privileges of citizens, so many of the blessings of Christianity ${ }^{36}$.

No doubt Guizot would have been pleased to find his political principles so readily adaptable to English culture. Still, when passages such as these are then translated into French, without explanation or adaptation, their effect is quite different as the values and political realities which are praised are either non-existent or not as generally accepted in France:

[...] ces leçons [Guizot's] ont évidemment pour dessein et pour effet, dans leur ensemble comme dans leurs détails, de célébrer et de mettre en lumière, dans toute sa beauté, le grand système social que

${ }^{35}$ François Guizot, Histoire, p. 7. As noted above, nothing in the English edition directly indicates that $\mathrm{Mr}$. Talboys is the translator.

${ }^{36}$ François Guizot, History, p. iii. 
nous possédons, et qui nous assure déjà les droits et les privilèges de citoyens, en même temps que les bienfaits du christianisme ${ }^{37}$.

Aside from there not being anything anyone would recognize as a "grand système social" in 1840's France, an expression such as "les droits et les privilèges de citoyens" would still carry a revolutionary echo in post-Restoration France - something Guizot would not have wanted in any way associated with his ideas. Moreover, "les bienfaits du christianisme" would have identified Guizot with parties of the religious right in the French political context, that is with the very parties which had, some eighteen years earlier, banned him from teaching the lessons published in this text.

Yet despite all this, it is not at all clear that this edition, with its preface, would not have been authorized, or even approved of by Guizot. One element of the preface would likely override all these negative associations. It is the "we", the "nous" which operates as shifter in both English original and French version and which here at once crosses linguistic, cultural and political borders ${ }^{38}$. The assertions it makes in French, precisely because they are so contradictory in the French political context, come then to suggest an imaginary, peaceful co-existence of opposing factions under the aegis of a well-ordered democracy - one which is in sharp contrast to the confrontational style of politics Guizot sees as the norm in France. In the end, this imaginary French "nous", though come to life only through mistranslation, is not without some resemblance to Guizot himself; to the Guizot who, in that diplomatic conversation beyond political difference, allowed himself to be enticed into "parfait abandon", imagined himself beyond national or linguistic borders and drifted somewhere ahead of history.

McMaster University

${ }^{37}$ François Guizot, Histoire, p. 7 [emphasis added; G. L. M.].

${ }^{38}$ An adapted translation of the preface would, for example, have made explicit that it was here a matter of English "rights and privileges" and would have accounted for "the blessings of Christianity" as a specifically English commonplace. 


\section{References}

BROGLIE, Gabriel de (1990). Guizot. Paris, Perrin.

GUIZOT, François (1838). Democracy in Modern Communities. "Translated from the French of M. Guizot", London, C. \& H. Senior.

- (1873) [1809]. Dictionnaire des synonymes de la langue française, Paris, Librairie Académique Didier et cie.

- (1840) [1829-32]. Histoire générale de la civilisation en Europe depuis la chute de l'Empire romain jusqu'à la Révolution française. Bruxelles, Gregoir, Wouters \& Cie.

- (1837). General History of Civilization in Europe from the Fall of the Roman Empire to the French Revolution. Oxford, D. A. Talboys.

- (1872). Mémoires pour servir à l'histoire de mon temps. 8 volumes, Paris, M. Lévy.

LEFORT, Claude (1992). Écrire à l'épreuve du politique. Paris, Calmann-Lévy.

ABSTRACT : Diplomacy Beyond Language: François Guizot and Translation - Neglecting to mention translation, ignoring the need or even the presence of translation is common practice in non-literary French writing in the first half of the nineteenth century. Still, in the case of François Guizot (1787-1874) such neglect seems to have a more deliberate motivation. Before becoming prime minister of France or ambassador to England, Guizot had translated several important English texts into French. His later marginalization of linguistic difference appears more rooted in his ideological perspective on history. Guizot's writings on French and English history and on the evolution of language seem to indicate that, for him, in the long run of history, translation would become obsolete. Nations, like languages, appear, from his point of view, to be drifting towards an ultimate unity, to flow irresistibly towards a utopian equality wherein differences political or linguistic - will ultimately be dissolved. 
RÉSUMÉ : Au delà du langage, la diplomatie. François Guizot et la traduction - La critique s'intéresse généralement très peu à la traduction ou aux traducteurs des textes non littéraires écrits en France au début du XIX ${ }^{e}$ siècle. Cependant, ce genre d'omission semble plus particulièrement volontaire dans le cas de François Guizot (1787-1874) qui, avant d'être nommé Premier ministre de la France ou ambassadeur en Angleterre, a traduit en français d'importants textes anglais. Les fondements de sa réflexion sur la différence linguistique apparaissent distinctement dans la représentation idéologique qu'il fait de l'histoire. Les écrits de Guizot sur l'histoire de la France et de l'Angleterre, ainsi que ceux traitant de l'évolution de la langue, semblent indiquer que la traduction deviendrait, avec le temps, une pratique désuète. Selon lui, les nations, tout comme les langues, se dirigeraient naturellement vers une unité ultime, une égalité utopique où les différences - politiques ou linguistiques - seraient définitivement abolies.

Key Words: politics, diplomacy, language, history, Guizot.

Mots clés : politique, diplomatie, langue, histoire, Guizot.

Gabriel Louis Moyal: McMaster University, Department of French, 1280, Main Street West, Hamilton, Ontario, L8S 4M2, Canada.

E-Mail : moyalg@mcmaster.ca 